\title{
LAWS, MORALS AND POLITICS
}

\section{Robert J. Burkhardt}

For some years it has not been popular to hold a version of the thesis that there is a necessary connection between 1 aw and morality, a thesis usually taken to mean that one cannot refer to a social norm which is in some way immoral as "valid law." This, in any case, is what Thomistic and Neothomistic "natural law theorists" conceive to be the significance of law and morality as "necessarily connected." And this, given the presumptions concerning morality which are involved in the Thomistic position, may be what accounts for the current unpopularity of the position. I will argue that the Thomistic variation on the theme of a necessary connection between law and morality is indeed only one interpretation of the theme, for which alternative scores have been written--ones which allow a considerable amount of improvisation.

Specifically, I will address some of the implications of Ronald Dworkin's conception of a political moralityl which is involved in the adjudication processes of a legal system. Dworkin's position is, simply, that in arriving at their decision, judges are guided by, and ultimately bound to, the political-moral doctrine which a particular legal system embodies. This political morality may only be explicated, or may only come to the surface, in "hard cases" 2 --cases where legal rules seem not to apply neatly, forcing a considerable degree of "interpretation." But the point is that that political morality is there all along. Dworkin's analysis not only criticizes and rejects both the "natural law theorists" and the "legal positivists" as these latter two schools of jurisprudence view the relation of law and morality, but, I will argue, provides a more plausible and realistic methodology for jurisprudence in general in the process.

1. Traditional Natural Law Theory. Intellectual history has yielded numerous versions of the view on law and the legal processes which holds that the "essence of law" is incomprehensible without reference to moral standards. Justice is the supreme social moral standard, so law without justice is essentially not Jaw. As Aquinas 
. . that which is not just seems to be no law at all. Hence the force of a law depends upon the extent of its justice.... Every human law has just so much the nature of law as it is derived from the law of nature. But if in any point it departs from the law of nature, it is no longer a law but a perversion of law. 3

Aquinas' position best represents the traditional natural law school, though others, notably Augustine, and more recently D'Entreves, 4 hold views on law which appear essentially the same as that stated above by Aquinas. There exists for all three, and for others as well, 5 an absolute canon or criterion of morality as this enters the social sphere; call it Reason, Justice, the Law of Nature. All social norms, to be called law, must conform to this. While social norms may have an effect on the behavior of individuals under that particular system of norms, unjust laws cannot be said to obligate those individuals. Instead, they merely coerce.

It should not be thought that natural law theory represents a completely homogeneous tradition. Indeed, Aquinas' account and D'Entreves', for example, differ in the particular rules which are casuistrically derived from the Supreme Criterion. Aquinas and Augustine differ over the place of "business" in society's laws. D'Entreves goes so far as to disclaim the theological basis which traditionally had been the cornerstone of natural law theory, offering instead a "humanistic" conception with no theological implications. Philip Selznick 6 offers a "sociologically-based" conception which is again different from Aquinas, Augustine and D'Entreves and closer to llobbes in using social and historical considerations as providing the conception of Justice which necessarily informs law. In spite of the numerous variations in the details of the particular natural law theoretical accounts, however, the basic conception is the same throughout the tradition--there is a singular, absolute and moral criterion which is thought definitive of the essence of law. What is fundamental is that law and morality are essentially, definitionally connected. Indeed it is logically impossible to "think them apart."

llistorjcally, natural law theorists have been an easy mark, for other than purely antireligious reasons. Numerous theorists including representatives from positivist, legal realist and sociological jurisprudence traditions in legal theory have found the tradition maintaining a necessary connection untenable. Hans Kelsen, for example, suggests that 
If it is assumed that the law is moral by nature then, presupposing an absolute moral value, it is meaningless to demand that law ought to be moral. Such a postulate is meaningful only - . if the possibility of the existence of an immoral law is admitted, if, in other words, the definition of law does not include the element of moral content. 7

Unfortunately, Kelsen begs the question involved in refuting the natural law position. For Kelsen posits from the outset that what is involved in the position is the definition of law as moral when he already assumes that the word "law" can be used independently of its conformity with the absolute moral canon. Hence Kelsen already talks past the natural law theorists who will, it should be noted, assent to their being "law-like norms" "in nature," though these are to be distinguished from "legally valid norms" "of nature." So Kelsen is off base.

But Alf Ross is not. Ross argues ${ }^{8}$ that the natural law theorists involve themselves in mistakes in epistemology and psychology, and exhibit practical ingenuousness in holding their definitional moral canon. Natural law theorists presume, says Ross, that the certainly they feel concerning the "necessity" of law and moral standards being connected is the ground for truth. This is wishful thinking. Certainty may provide a "limiting case" for the truth of a claim, but does not suffice to establish that truth. Indeed, that Aquinas saw justice in law as somehow best does not establish that there exists no law without justice. These are psychological errors.

This latter point focuses in upon the linguisticepistemological error in the natural law tradition. For, while--after Plato and (perhaps) Aristotle--it was fashionable to think in terms of "eternal essences", if the "eternal essence" of Law is discoverable, it is not solely by reason of intuition (again perhaps products of wishful thinking), but by perception. Are we to deny the appelation "law" to, say, a non-Christian or perhaps unjust social-political norm-systems? To think this is to make a mistake in epistemology.

But this last mistake shows also the practical naivete of natural law theorists (not wishing to attribute insidiousness). For to deny calling a particular civil order a legal system, in the "real" sense, may be revolutionarily or reactionarily useful for a particular group in a society. If those norms are not law, they are not anything to us. 
Ross's criticisms do not, I believe, do severe injustice to the positions of the natural law theorists, at least not to those who maintain the necessary connection between an absolute moral criterion (existing naturaliy) as definitive of the essence of law. The question is one of methodology, colored by a perception that values enter procedures for examination at any number of levels. For the natural law theorists begin by assuming that they "have" the essence of law, that it is moral, and that it is of a particular moral nature. In other words, like Kelsen who believes he can use the word 'law' independently of reference to morality, the natural law theorists believe the opposite that the very use of 'law' entails a particular moral essence. The difficulty for the natural law theorists is thus Kelsen's difficulty: there is an imnediate begging of the question, which as Ross's critique should suggest, must be prompted by a prior valuation of the "moral essence." I should like to suggest that a Wittgensteini.an-like directive may sidestep these problems: "Look and see," discover if there is in fact an "essence" of law, a "core meaning" for 'law'; then a determination of whether that essence is a moral one, and only then whether the moral essence is a justifiable one may be in order. Though it is to imediately throw oneself into the realm of moral philosophizing, with all the attendant problems with reason and justification, it may be that the law is essentially moral but that no moral position is ever rationally justified. I should like to leave this issue aside. The point is that natural law theory rests upon an important methodological mistake, as does, I now wi.ll argue, the contrary position, legal positivism.

2. The Positivist Separability Thesis. Positivist legal theorists, from Bentham and Austin10 to their successors llart and Kelsen, have had the best of intentions. H. L. A. Hart notes that the position which was introduced (or more precisely popularized) in legal theory by Bentham to counter the ills (methodological and practical) of the traditional natural law doctrine was introduced ". . to enable men to see steadily the precise issues posed by the existence of morally bad laws, and to understand the specific character of the authority of the legal order."II Bentham and Austin, it should be noted, were first reformers--Bentham for utilitarian ends, Austin For Christjan-utilitarian ends. In this regard, both wished to draw a distinction between law and morality for eninently practical reasons--to criticize the exjsting legal framework. And in this regard both recognized the reactionary use to which natural law theory's identification of laws and morals could be (and was being) put. But their objection rested on more methodological grounds, which llart was able to frame most precisely. 
Hart's contention is that Austin's, Bentham's, his own and Kelsen's view on the relation of law and morality is that while legal and moral norms may overlap in a given social system, the law must nevertheless be understood, explained without reference to moral considerations. That is, one can and must define law. independently of morality for any moral criticism of law to make sense, or, for that matter, for any legal criticism of law to make sense. Hart's methodological point is that the natural law theorists too readily blur the distinctions between, say, just law and de facto coercive powers; if a de facto coercive authority could be explained as a legalisystem, then the phrase, "morally bad law" has meaning. If a de facto authority is not a legal authority, then "morally bad law" is nonsense. which

Kelsen offers in this light a "pure theory of law,"

- . describes the law and attempts to eliminate from the object of this description everything which is not strictly law: its aim is to free the science of law from alien elements...

[which] obscure(s) the essence of the science of law and obliterates the limits imposed upon it by the nature of its subject matter. 12

The quest is then for a positivist science, an analysis and description of the legal system which is, presumably unlike the analyses offered by the natural law theorists, "value free."

But far from the methodological-scientific point, Kelsen and llart proceed actually to undertake the nonmoral analysis of law. Hart suggests that "the law" is essentially only a "union of primary and secondary rules."13 Neither the primary (obligation) rules nor the secondary (procedural) rules need embody moral content, or need reflect a certain criterion of Justice, Reason or Good. Similarly, Kelsen suggests that ". . . the difference between $l$ aw and morals can be found... in how they command or prohibit certain behavior. . ; law is a coercive order...; whereas morals is a social order without such sanctions."14 The nonmoral analysis of the legal system thus yields descriptions of law which are not only themselves devoid of any evaluations, positive or negative, of the object of the enquiry, but which also slow "the law" as essentially devoid of moral evaluations. Law is law; and morals are morals. 
In practice, both Kelsen and Hart admit of morality in law. Hart notes at length that not only is it true that in the United States and in England are moral principles, like principles of justice, incorporated into the basic structure of the legal institutions,

The further ways in which law mirrors morality are myriad, and still insufficiently studied: statutes may be a mere legal shell and demand by their express terms to be filled out with the aid of moral principles; the range of enforceable contracts may be limited by reference to conceptions of morality and fairness; liability for both civil and criminal wrongs may be adjusted to prevailing views of moral responsibility. Ilo 'positivist' could deny that these are facts, or that the stability of the legal systern depends in part on such types of correspondence with morals. If this is what is meant by the necessary connection of law and morals, its existence should be conceded. 15

Hart's admission that in fact law and morality are not "necessarily unconnected" goes a long way toward strengthening the position of the legal positivists in the face of criticisms to the effect that positivism is an "abstracted, merely formalistic" way of looking at law. 16 But Hart's admission also forces an evaluation of precisely what the positivists are saying. For Kelsen makes the point that

- : if, presupposing only relative moral values, the demand is made to separate law and morals in general, and law and justice in particular, then this demand does not inean that law and morals, law and justice are unrelated; it does not mean that the concept of law is outside the concept of the Good. 17

This raises the question, what if only relative moral values are presupposed? That is, could it be that the natural theorists are wrong, not about law, but about morality?

With the exception of Hart, who is a utilitarian of surts, 18 it is safe to say that contemporary legal positivists are moral noncognitivists. Their position vis-a-vis the place of morals in law denies any

singular, absolute canon of morality as definitive of, or even explicative of, the "essence of law," because, 
simply, there is no such canon of morality. Indeed, all moral judgements or moral criteria are only "ejaculations" or personal preference-statements. Hart's position is a bit more complex, implying as he does that there may be a way to arrive at a "greatest welfare principle." Still, Hart sides with the positivist-emotivists in believing that there is no singular moral criterion which is definitive of the essence of 1 aw. But that no particular moral criterion is definitive of law does not mean that (as Kelsen seems to suggest) not any moral criterion is definitive of law. Indeed, morality may necessarily enter law, though not the theistically grounded morality of Augustine and Aquinas, nor the rationally intuited morality of D'Entreves, nor the sociologically-derived morality of Selznick.

The positivist position can be objected to on two levels. First, an objection similar to that raised against the natural law theorists can be offered: in denying the connection between the definition of law and that of morality, the positivists may be begging important questions concerning the nature of definition. If there is a connection between law and morality in every legal system which could exist, then to say that there is no logical connection between law and morality is to posit a "disembodied essence" for law. Positing an essence may not, as such, be mistaken, if that is conceived as a "modeling" activity, akin to the utilization of geometric representations of "pure competition" in economic theory. But the dangers involved in this modeling activity are similar to those pointed out by Ross concerning natural law theory--psychological, and epistemological errors ultimately giving rise to practical dangers. Hart's "model of rules" and Kelsen's "pure theory," in modeling law without reference to moral norms, falls into this danger, of serving to promote a nonevaluation of the results of the "value free" science.

On a second level, perhaps more substantive criticisms can be offered. For both Hart and Kelsen, while recognizing the coercive effect of social norms (which they claim as the essence of law) fail to see those coercive norms as operative in a political-moral order. That is, while Kelsen, for instance, wishes to deny that political ideology or moral judgement enters legal theory, what he produces is a theory which does not explain how political ideology and moral judgement enter law itself. The methodological mistakes succeed in generating descriptive ingenuousness. Similarly, Hart, recognizing "overlap" of law, morals, and politics, cannot concede that there is more at work in the law than just that overlap. Indeed, the overlap is essential to defining and explaining law. 
These criticisms suggest that as regards the relation of law and morality, positivism as a legal theory suffers, as does natural law theory, from telling only half the story. On the one hand, natural law theory cannot describe law without reference to the absolute moral standard of Justice, Reason or Good. On the other hand, legal positivisin cannot describe or define law with reference to the moral standards operative in a society. I wish to argue at this point that Dworkin's analysis of "political morality in law" is a more adequate representation of the "essence of law," for its avoidance of the pitfalls which Ross, for one, has pointed out as "there to be avoided" in legal theory.

3. Dworkin's Non-separability Thesis. 19 On the surface, Ronald Dworkin's argument is directed against Hart's "model of rules" mentioned above. But interestingly Dworkin's thesis is, at least concerning law and morality, not one which llart, in his less "positivistic" moments, inay wish to deny. Dworkin argues that (1) contra Hart and Kelsen, judges do not have "discretion in the strong sense" to make law where the specifically legal rules do not apply neatly; (2) judges are rather bound to interpret statutes in the light of a political morality which the legal systein embodies; (3) such interpretations are "internal to law," and create legally obligating precedent; and (4) in spite of the fact that political morality as such is in law, we still need to evaluate, morally, that "positive morality." On close inspection, llart for one may agree with (3) and (4). This possible point of agreement is where $I$ will focus my attentions.

(1) Dworkin's argument that judges do not have "discretion in the strong sense" 20 rests with two claims, one linguistic, the other behavioral. For one, Hart had angued that the "nature of rules" dictates that interpretations will often be arbitrary, since first, rules are general and do not "pick out instances of themselves," and secondly, instances are particular and individualized, and do not "pick out rules for themselves." 21 So "fitting a rule and instance" is a matter of judgement, the arbitrariness of which is determined by the vagueness and generality of the rule. This "fact" of arbitrariness suggests a considerable degree of "judicial discretion." Dworkin claims, however, that laws are formulated not only as rules, but also as principles and policies, the former dictating "ways of treatment" of cases, the latter dictating consequences to be achieved by a decision. So while rules may allow discretion, the principles and policies of law narrow the range of this discretion to certain "ways of treatment" and consequences to be achieved." Hot all (written) laws are rules, so rule interpretation is not all there is. Tlis is just a fact about the "language of law." 
But this also shows in the behavior of judges. Hart seems to assume that judges allow themselves a considerable degree of discretion, in that they are forced to create law in certain cases by the absence of determinate rules. Dworkin counters this, however, in suggesting that judges will find a principle or policy in law to justify their decision as a legal, "valid," pronouncement. Granted, no one can say that the reason why the judge "found" that principle was the principle itself. But it is the principle (or policy), and not the judge's "reason for holding it" which counts as law. Dworkin suggests that "discretion in the strong sense" does not exist.

(2) If judges must interpret law in light of rules, principles and policies for their holding to be real law, then judges as judges are bound, obligated by, these principles, rules, and policies in law. llart had maintained that precedent, for instance, was too weak and ambiguous to obligate judges legally.22 But as Dworkin sees it, this is to fall back on the rule analysis. The principles and policies (more the former than the latter) of law may be vague, but not ainbiguous. And, in fact, the body of "common law," the decisions of judges embodied in precedent, forms a more or less coherent set of doctrine concerning rights, personality, liability, and the moral and political worth of individual action. Besides the fact that judges are for the most part "political creatures," aware of the sources of and beneficiaries of their exercise of authority, they are also "roles"--with definite professional responsibilities attached. Part of these responsibilities is the requirement that they "understand" the political and moral traditions of their office, including the traditionally developed common law doctrine having moral and political content. So, by yirtue of their legal position judges are legally bound (though perhaps no determinate rule gives this obligation) to follow political, moral, and legal precedent. Dworkin calls this the "doctrine of political responsibility."23 Again, the point is that discretion is significantly weaker than the positivists allow.

(3) Part of the positivist program was the desire, articulated above by Kelsen, to free law and legal theory of "alien elements." In Kelsen's work this amounted to modeling law after scientific theorv (from the positivist perspective), complete with "pyramidal structure."24 In Hart's work, this amounts to distinguishing an "internal point of view" on law which "sees the obligatoriness" of certain behaviors from an "external point of view" 25 which sees orly patterns or regularities of conduct. Hart's approach follows the 
post-Wittgensteinian tradition in social science 25 of maintaining that certain "criteria of identity" are visible only after certain "basic reasons"--intrasystemic rationales--are accepted by the observer. From the position of maintaining some things as external to law, both Kelsen and Hart reiterate their arguments that since judges use non-rule guidelines in formulating their decisions, the judicial decision marks a "limit of law," a "gap in the law." 27

Dworkin counters by rejecting first the pyramidal view of the legal system. Especially in those nations which have constitutional "separation of powers" and even in those legal systems which do not, there is no neat system of internal relations proceeding from the top down, nor from the bottom up. "Legality" is spread across the entire legal system. And Dworkin further rejects the idea that the "internal criteria of law" can ever be precisely formulated, so that a singular line of demarcation can be drawn to differentiate "this as law" from "this as not law." The argument to the effect that political and moral doctrine are in precedent, which is legally binding on judges, is offered in support of this.

If there is an "internal point of view," however, it must be understood as the basic legitimation processes of the whole legal-political-moral order. We may wish to say that, say, from a liberal western democratic position, South African "legal practice" does not appear as law. Or, we may wish to say that a certain renegade (or perhaps senile) judge's behavior is "marginal" to law. These amount to taking certain "criteria of identity," though now moral-political, as well as "formally legal" canons as operative in the acceptance of the "internal point of view."

These considerations lead directly into the next point, the need for an evaluation of the political-moral criteria which are embodied in law through both the judicial decision as well as the legislative enactment. But the final point to be made with regard to the "internality" of these criteria is that, simply, what else could it be? A logical, or an empirical investigation of social norns may be able to isolate specifically legal norms, say, a 55 mile per hour speed limit; or such an investigation may be able to isolate a specifically moral norm, say, a Southern Baptist prohibition against partaking of alcoholic spirits. But when one looks at the activities involved in "the law" one must see that the distinctions between law and morality become blurred. As Dworkin suggests, this blurring is 
only most visible in the judicial decision colored by interacting moral, political, economic and personal standards. Still, it exists in all aspects of social life. Many "criteria of identity" are operative, internally to law.

(4) In the Hart-Devlin debates 28 of the last decade, Hart took up the position articulated by Austin concerning the place of "positive morality" in law. The idea was that a certain political morality does in fact exist in law, which perhaps reflects the "community standards" against, say, homosexual activity. That this positive, politically operative moral code may be mistaken is, however, always a danger. Indeed Austin thought that only if this positive morality were evaluated vis-a-vis "God's law" could it be justified. And similarly llart thought that not only were certain incoherencies attached to the idea of a community moral code, but that this must be critically evaluated as well.

Dworkin's final point against the positivists (though here again Hart may be forced to agree) is that the positive, political morality which is embodied in the common law must be criteally justified. Where Dworkin differs with Hart is in the description of what must be justified. For llart thought it only contingent to the definition of law that this positive moral code be included in his description. Dworkin thinks it essential to understanding what law is, and what law does, that the political morality be fully understood. For the political and moral doctrine embodied in the common law conditions the canons of legality, and indeed dictates how certain community moral judgements may enter the legal process. If, for instance, the operative traditional political morality "takes rights seriously," to borrow Dworkin's phrase, while the community standards take a turn to the right in negatively evaluating homosexual human beings' freedoms, problems arise in the justification of the (rights-protecting) judicial judgement. We are forced to look very hard, and very critically, at both the community evaluation as well as the traditional political-moral doctrine. One may have to give.

For the validity (the internal criterion of legal adequacy) of the law may rest with the critical evaluation of community moral standards (perhaps reflected in legislative enactments) 29 and traditional common law doctrine (perhaps reflected in supreme or even lesser court decisions). That Dworkin sides in general with the court decision respecting rights above all matters of democratically enacted moral judgements is not at issue here. The importance of his analysis rests with 
the identification of how morality necessarily enters our description of law. Armed with this more realistic perception, inen may perhaps be better able to "see steadily the precise issues posed by the existence of morally bad laws."

4. Concluding Note: Politics and the Internal Morality of Law. To a large extent, Dworkin's position resembles that of Lon Fuller, whose argument for a certain "internal morality of law" 30 prompted numerous criticisms from the positivist camp. Fuller argued that certain conditions, for example, generality, non-retroactivity, noncontradictoriness, constancy through time, congruence between law and official action, were necessary, in the definitional and descriptive sense we have been discussing, for law per se to exist. Fuller was justly criticized 31 for ideologically "building in" too much in the way of liberal democratic political doctrine into his specifically legal theory even though fuller thought himself describing "the law" in much the same way as the positivists had done. To say, for instance, that "the law" must not be retroactive may either be to place a democratic-moral condition on the law, or to pass into a purely "functional" description of law which presupposes a positivistic account in the first place. Fuller's conditions are either "truisms," similar to Hart's "minimal natural law" 32 conditions, or he has not gone far enough.

With Dworkin's account of the necessity of politicalmoral considerations entering law, however, we can begin to salvage Fuller's conditions. For Fuller's canons may indeed be descriptive of the law per se from within a particular political-moral common law tradition. And Since Fuller's conditions appear to represent just those criteria operative in a liberal western constitutional democracy like the United States or West Germany, the canons may not be absolute. But then again, they may be. In line with Dworkin, they very well may be--but only if we can arrive at a reasoned critical justification of the political-moral doctrine which they embody.

Ultimately, the test of a legal theory is how it proceeds when we "get down to cases." Very recently, 33 a number of critics have done just this with regard to Dworkin's thesis concerning political morality entering law through the judicial decision. The results of this new "twist" in the dialogue (or more precisely "trialogue") between Dworkin, positivism and natural law theorists remains to be seen. My intuition is that Dworkin will. "win." 
For a second ultimate test of a legal theory is how well it coheres with our "considered judgements" about what actually goes on in the legal system. The law, to my eyes, is only a part of an ongoing process of social control, social integration, interpersonal exchanges. The whole process, involving as it does perhaps an overabundance of interacting and conflicting moral, political, econoric, personal, and so on, evaluations, perhaps may never be completely understood. It does no good, however, to formulate models, the "fit" of which to the actual process is at best strained, at worst wrongheaded. Though Dworkin's thesis allows considerable "play," I suggest that it is to the point--that point where law and morality necessarily relate.

Florida State University. 
NOTES

${ }^{1}$ For an explication of Dworkin's notion see Ronald Dworkin, Taking Rights Seriously (Cambridge, Mass.: Harvard University Press, 1977), especially chapters I through $V$.

${ }^{2}$ Cf. "Hard Cases" in Dworkin, pp. 81-150.

${ }^{3}$ Thomas Aquinas, Summa Theologiae I-II, q. 95 ; quoted in Martin P. Golding, The Philosophy of Law (Englewood Cliffs: Prentice- $\overline{\mathrm{Hall}}$, Inc., 197.5), P. 30.

${ }^{4}$ A. P. D'Entreves, Natural Law (London: Hutchinson University Press, 1951); "The Case for Natural Law Reexamined" Natural Law Forum (1956).

${ }^{5}$ For example, Jean Dabin. Cf. "Is There a Juridical Natural Law," in Martin Golding, ed." The Nature of Law (New York: Random House, 1966), pp. 25-34; Hegel, Hobbes, Kant, Locke and others all have been placed in the natural law tradition by one or another author.

${ }^{6}$ Philip Selznick, "Sociology and Natural Law," Natural Law Forum

7 Hans Kelsen, The Pure Theory of Law (Berkeley: University of California Press, 1970), Pp. 66-67.

${ }^{8}$ Alf Ross, On Law and Justice (Berkeley: University of California Press, 1958), pp. 258-63.

${ }^{9}$ Cf. Jeremy Benthain, An Introduction to the Principles of Morals and Legislation (New York: Columbia University press, 1945).

${ }^{10} \mathrm{Cf}$. John Austin, The Province of Jurisprudence Determined (London: Weidenfield and Nicolson, 1954).

${ }^{11_{H}}$. L. A. Hart, "Positivism and the Separation of Law and Morals," Harvard Law Review 71 (1958): p. 41.

12 Kelsen, p. 1 .

${ }^{13}$ For a complete explication of Hart's view of law see H. L. A. llart, The Concept of Law (Oxford: Oxford University Press, $1 \overline{96}$, , especially chapters IV and $V$. See also Hart, "Definition and Theory in Jurisprudence," Law Quarterly Review 37 (1954). 
14 Kelsen, p. 62 .

15 llart, The Concept of Law, 199-200.

${ }^{16}$ Ross, for example, discusses this problem with most positivist accounts. See Ross, pp. 65-66. On the other hand, Hart refutes "rule scepticism" and the criticism of formalism. See Hart, The Concept of Law, chapter VII.

17 Kelsen, p. 66 .

${ }^{18}$ See 11. L. A. Hart, Law, Liberty and Morality (Stanford: Stanford University Press, 196 3 ).

19 The major part of the following discussion is based upon the collection of Dworkin's (auto-edited) papers, Taking Rights Seriously. Especially important for my purposes are "Hard Cases," chapter IV, and "Model of Rules I, II," chapters II and III.

20 Dworkin, p. 31 .

$21_{\text {Hart, }}$ The Concept of Law, 122-2\%.

22 Ibid., p. 131.

23 Dworkin, p. 87 .

24 The phrase is Dworkin's, but a quick examination of any of the positivistic philosophers of science will reveal that the law-theory-hypothesis-observation scheme is pyramidal, as opposed to "weblike." After Quine we almost have to buy the latter.

25 The internal-external point of view distinction is the stickiest concept in llart's theory, and for this reason I wish to pass it by quickly here. I do not believe that it significantly effects the point I am making here, especially when viewed through the eyes of Roscoe Hill, who says in effect that Dworkin's point concerning law and morality is essentially compatible with a modified Hartian framework. See lli.11, "Legal Validity and Legal Obligation," Yale Law Journal 80 (1970).

${ }^{26}$ I have in mind Peter Winch's classic The Idea of a Social Science (London: Routledge and Kegan Paul, $\overline{1} 9 \overline{58)}$.

27 Kelsen, (p. 230) makes a half-hearted attempt to deny that there are gaps, since judges "fill them in." There have to be gaps to have them filled, however. 
28 The Report of the Committee on Homosexual offenses and Prostitution, or Wolfenden Report, prompted Lord Patrick Devlin to publish The Enforcement of Morals (London: Oxford University Press, 1965), which was followed by llart's criticisms of Devlin's position, "Social Solidarity and the Enforcement of Morals," Chicago Law Review 35 (1967). The latter article restates a number of Hart's arguments from Law Liberty and Morality (Stanford: Stanford University Press, $1 9 6 3 \longdiv { \text { . } }$

${ }^{29}$ In his recent book, The Moral Criticism of Law (Encino: Dickenson Publishing Company, 1977) David A. $\mathrm{J}$. Richards attempts to make a case for the countermajoritarian tendency of the courts on the basis of this distinction between majority legislative activity, and common law judicial activity. (Richards uses the constitution as exemplifying the "merger" of these two.)

${ }^{30} \mathrm{Cf}$. Lon Fuller, The Morality of Law (New Haven: Yale University Press, 196 6 ), pp. $4 \overline{6-9} \overline{1 .}$

${ }^{31}$ Cf. Alan R. Mabe, "The Relationship of Law and Morality," Southern Journal of Philosophy 12 (1974).

${ }^{32}$ Hart, The Concept of Law, chapter $X$, pp. 181-207. Hart's minimal conditions on law are (i) human vulnerability; ( $i$ i) approximate equality; (iii) limited altruism; ( $i v)$ limited resources; ( $v$ ) limited understanding and strength of will. While not like Fuller's more "legalistic" conditions, in practice they would very probably work out to something like Fuller's conditions.

${ }^{33}$ I have not been able to consider here the recent Georgia Law Review symposium on Jurisprudence (September 1977) which includes a number of critical articles on Dworkin's views and a reply by Dworkin. The collection looks very promising. 